\title{
Micronutrient Availability as Influenced by Household Waste based Vermicompost Application in Calcareous Soil of Bihar during Rice Growth Period
}

\author{
Alpana Kusum ${ }^{1 *}$, Shankar Jha ${ }^{2}$, S. S. Prasad ${ }^{2}$ and S. P. Singh ${ }^{2}$ \\ ${ }^{1}$ Department of Soil Science and Agricultural chemistry, Bihar Agricultural University, \\ Sabour, Bihar, 813210, India \\ ${ }^{2}$ Department of Soil Science, Dr. Rajendra Prasad Central Agricultural University, Pusa, \\ Bihar, 848125, India \\ *Corresponding author
}

\section{A B S T R A C T}

A pot experiment was conducted during Kharif 2018 at RPCAU, Pusa to find out the effect of vermicompost prepared from household waste and cow dung $(1: 1$, w/w) onDTPA extractable micronutrients: Iron (Fe),

Keywords

household waste, vermicompost, Diethylenetriamine Pentaacetic Acid (DTPA) micronutrient, rice, post-harvest soil

Article Info

\section{Accepted:}

08 January 2020

Available Online: 10 February 2020 Copper $(\mathrm{Cu})$, Zinc $(\mathrm{Zn})$ and Manganese $(\mathrm{Mn})$ status in soil during rice crop growth. There were four levels of vermicompost along with three levels of chemical fertilizers. Results indicated that an increasing trend was observed in DTPA extractable micronutrients in soil from transplanting to tillering stage whereas a gradual decline was observed in post-harvest soil. However, in post-harvest soil content of available micronutrients was low as compared to tillering stage but was greater than initial soil micronutrients content for all the treatment combinations except control which indicates a significant build-up of available micro-nutrients in postharvest soil of rice on application of graded dose of vermicompost alone or in combination with different dose of fertilizer. The extent of build-up was higher under higher dose of vermicompost and fertilizer. Treatment involving application of vermicompost $\left(2.5 \mathrm{t} \mathrm{ha}^{-1}\right)$ along with full dose of fertilizer (RDF) emerged out as best treatment combination with respect to micronutrient nutrient availability.

\section{Introduction}

Rice (Oryza spp.) is a major crop which covers one third of total cultivated area of
India and provides food to more than half of the Indian population. In India, rice is cultivated in $43.8 \mathrm{~m}$ ha with production of 168.5 million tonnes and productivity of $3848.0 \mathrm{~kg} \mathrm{ha}^{-1}$ (FAO Stat, 2017). Adoption of 
inadequate agricultural practices and injudicious fertilizer management causes adverse impact on soil health and create nutrient imbalance and micronutrient deficiency.

Low levels of soil fertility, deteriorating soil health and micronutrient deficiency are the main reasons behind lower agriculture production. The micronutrients ( $\mathrm{Zn}$ and $\mathrm{Mn}$ ) are essentially involved in metabolism of rice plants. Among micronutrients the deficiency of $\mathrm{Zn}$ and $\mathrm{Mn}$ is predominant in soil and $\mathrm{Zn}$ deficiency has been observed as the major limiting factor in rice growing regions. It has been reported that soils in rice and wheat growing regions are prone to $\mathrm{Zn}, \mathrm{B}, \mathrm{Mn}$, $\mathrm{Fe}, \mathrm{Mo}$ and $\mathrm{Cu}$ deficiencies (Rashid, 2005). Micronutrients are equally important as macronutrients with respect to plant metabolic activities and growth.

The increasing cost of fertilizers and its undesirable effects on soil properties have led to inclusion of organic manures as a supplement to chemical fertilizers in crop cultivation and as organic waste are rich in nutrients which can be converted to plant available form by vermicomposting.

Application of vermicompost in the field is known to enhance the quality of soils by increasing microbial biomass, microbial activity and enzymatic activity which are key components in nutrient cycling, production of plant growth regulators and protecting plants soil-borne disease and improves the quality of mineral nutrition (Arancon and Edwards, 2005) as well as plant nutrient uptake. Vermicompost improves the soil fertility, productivity and leads to higher yield (Padmavathiamma et al., 2008; Tharmaraj et al., 2011). Application of vermicompost prepared from organic waste in combination with chemical fertilizer can increase available nutrients and microbial population in paddy field as well as enhance plant nutrient uptake (Kale et al., 1992).Keeping these in view, the present studies were carried out.

\section{Materials and Methods}

A pot experiment was conducted in sandy loam soil of Dr. Rajendra Prasad Central Agricultural University, Pusa, Samastipur, Bihar during Kharif2018.The soil of experimental site belongs to order Entisol and is characterized as Calciorthents which is sandy loam in texture with alkaline $\mathrm{pH}(8.06)$, low in available nitrogen $\left(220 \mathrm{~kg} \mathrm{ha}^{-1}\right)$ and phoshorus $\left(17.80 \mathrm{~kg} \mathrm{ha}^{-1}\right)$ while medium in available potassium $\left(146.5 \mathrm{~kg} \mathrm{ha}^{-1}\right)$ and DTPA extractable $\mathrm{Fe}\left(6.90 \mathrm{mg} \mathrm{kg}^{-1}\right), \mathrm{Cu}(0.71 \mathrm{mg}$ $\left.\mathrm{kg}^{-1}\right), \mathrm{Zn}\left(0.74 \mathrm{mg} \mathrm{kg}^{-1}\right)$ and $\mathrm{Mn}\left(3.07 \mathrm{mg} \mathrm{kg}^{-}\right.$ $\left.{ }^{1}\right)$ initially.

The experiment was laid out in a Completely Randomized Design (Factorial) with three replications. There were four levels of vermicompost $\left(\mathrm{V}_{0}\right.$ :No manure, $\mathrm{V}_{1}$ : Vermicompost @ $1.25 \quad \mathrm{t} \quad \mathrm{ha}^{-1}, \mathrm{~V}_{2}$ : Vermicompost @ $2.5 \mathrm{t} \mathrm{ha}^{-1}$ and $\mathrm{V}_{3}$ : Vermicompost @ $3.75 \mathrm{t} \mathrm{ha}^{-1}$ ) along with three levels of chemical fertilizers $\left(\mathrm{F}_{0}:\right.$ No fertilizer, $\mathrm{F}_{1}$ : RDF and $\left.\mathrm{F}_{2}: 50 \% \mathrm{RDF}\right)$.

Recommended Dose of Fertilizer (RDF) $\mathrm{N}: \mathrm{P}_{2} \mathrm{O}_{5}: \mathrm{K}_{2} \mathrm{O}:: 120: 60: 40 \mathrm{~kg} \mathrm{ha}^{-1}$

Experimental crop- Rice

Variety- Rajendra Bhagwati

No. of pots and capacity- 36 plastic pots of 10 $\mathrm{kg}$ soil capacity

To find out the residual effect of vermicompost either alone or in presence of fertilizer on soil properties, the soil samples were collected from pots at transplanting, tillering stage and after harvest of crop and analyzed for DTPA extractable micronutrient $\mathrm{Fe}, \mathrm{Cu}, \mathrm{Zn}, \mathrm{Mn}$ and then it was processed statistically. 
Table.1a Effect of vermicompost and fertilizer on Fe availability in soil during rice growth period

\begin{tabular}{|c|c|c|c|c|c|c|c|c|c|c|c|c|}
\hline \multicolumn{13}{|c|}{ Available Fe $\left(\mathrm{mg} \mathrm{kg}^{-1}\right)$} \\
\hline \multirow{2}{*}{ Treatments } & \multicolumn{4}{|c|}{ Transplanting stage } & \multicolumn{4}{|c|}{ Tillering stage } & \multicolumn{4}{|c|}{ Post-harvest soil } \\
\hline & $\mathbf{F}_{\mathbf{0}}$ & $\mathbf{F}_{1}$ & $\mathbf{F}_{2}$ & Mean & $\mathbf{F}_{\mathbf{0}}$ & $\mathbf{F}_{1}$ & $\mathbf{F}_{2}$ & Mean & $\mathbf{F}_{\mathbf{0}}$ & $\mathbf{F}_{1}$ & $\mathbf{F}_{2}$ & Mean \\
\hline $\mathbf{V}_{0}$ & 6.45 & 8.58 & 8.54 & 7.85 & 7.61 & 10.12 & 10.08 & 9.27 & 6.04 & 8.83 & 8.79 & 7.89 \\
\hline $\mathbf{V}_{1}$ & 9.28 & 9.85 & 9.60 & 9.58 & 10.95 & 11.29 & 11.23 & 11.16 & 9.56 & 10.15 & 9.89 & 9.87 \\
\hline $\mathbf{V}_{2}$ & 9.95 & 10.18 & 10.07 & 10.07 & 11.84 & 12.01 & 11.95 & 11.93 & 10.25 & 10.49 & 10.37 & 10.37 \\
\hline $\mathbf{V}_{3}$ & 10.24 & 10.30 & 10.27 & 10.27 & 12.08 & 12.11 & 12.11 & 12.10 & 10.55 & 10.61 & 10.58 & 10.58 \\
\hline Mean & 8.98 & 9.73 & 9.62 & & 10.62 & 11.38 & 11.34 & & 9.10 & 10.02 & 9.91 & \\
\hline Sources & \multicolumn{2}{|c|}{$\operatorname{SEm}( \pm)$} & \multicolumn{2}{|c|}{$\mathrm{CD}(5 \%)$} & \multicolumn{2}{|c|}{$\operatorname{SEm}( \pm)$} & \multicolumn{2}{|c|}{$\mathrm{CD}(5 \%)$} & \multicolumn{2}{|c|}{$\operatorname{SEm}( \pm)$} & \multicolumn{2}{|c|}{$\mathrm{CD}(5 \%)$} \\
\hline Vermicompost (V) & \multicolumn{2}{|c|}{0.11} & \multicolumn{2}{|c|}{0.31} & \multicolumn{2}{|c|}{0.12} & \multicolumn{2}{|c|}{0.37} & \multicolumn{2}{|c|}{0.11} & \multicolumn{2}{|c|}{0.32} \\
\hline Fertilizer (F) & \multicolumn{2}{|c|}{0.09} & \multicolumn{2}{|c|}{0.27} & \multicolumn{2}{|c|}{0.11} & \multicolumn{2}{|c|}{0.32} & \multicolumn{2}{|c|}{0.09} & \multicolumn{2}{|c|}{0.28} \\
\hline $\mathbf{V} \times \mathbf{F}$ & \multicolumn{2}{|c|}{0.18} & \multicolumn{2}{|c|}{0.54} & \multicolumn{2}{|c|}{0.22} & \multicolumn{2}{|c|}{0.63} & \multicolumn{2}{|c|}{0.19} & \multicolumn{2}{|c|}{0.55} \\
\hline
\end{tabular}

The Available $\mathrm{Fe}, \mathrm{Cu}, \mathrm{Zn}, \mathrm{Mn}$ was determined by atomic absorption spectrophotometer after extracting the soil with DTPA based on the procedure described by Lindsay and Norvell (1978).

\section{Results and Discussion}

\section{Available micronutrients( $\left.\mathrm{mg} \mathrm{kg}^{-1}\right)$}

The results on contents of DTPA extractable micronutrients ( $\mathrm{Fe}, \mathrm{Cu}, \mathrm{Zn}, \mathrm{Mn}$ ) as influenced by application of vermicompost at four doses $\left(0,1.25,2.5\right.$ and $\left.3.75 \mathrm{t} \mathrm{ha}^{-1}\right)$ either alone or in combination with three fertilizers levels $(0$, $\mathrm{RDF}$ and $50 \% \mathrm{RDF}$ ) at transplanting, tillering stageand post-harvest soil of rice crop have been presented in Table 1a to 1d.

\section{Iron ( $\left.\mathrm{mg} \mathrm{kg}^{-1}\right)$}

The available Fe content (as shown in Table 1a) varied from 6.45 to $10.30 \mathrm{mg} \mathrm{kg}$ at transplanting stage. At tillering stage DTPA extractable iron varied from 7.61 to 12.11 $\mathrm{mgkg}^{-1}$.An increasing trend was observed in DTPA extractable iron in soil from transplanting to tillering stage whereas a gradual decline was observed in post-harvest soil. In post-harvest soil available Fe content ranged from 6.04 to $10.61 \mathrm{mg} \mathrm{kg}^{-1}$ which wasobserved low as compared to tillering stage but was greater than initial soil $\mathrm{Fe}$ content for all the treatment except control combinations involving application of vermicompost and it indicates build-up of available iron in soil.

DTPA extractable iron content of soil increased significantly with increasing levels of vermicompost and chemical fertilizer and the interaction effect was found significant during all the observational stages.

The treatment involving highest dose of vermicompost (3.75 $\left.\mathrm{t} \quad \mathrm{ha}^{-1}\right)$ recorded significantly higher available $\mathrm{Fe}$ content (10.55 to $10.61 \mathrm{mg} \mathrm{kg}^{-1}$ ) which was found to be at par with the treatment receiving vermicompost at $2.5 \mathrm{t} \mathrm{ha}^{-1}$ (10.25 to $10.49 \mathrm{mg}$ $\mathrm{kg}^{-1}$ ). The finding was in tunes with findings of Lakshmi (2011) and Supriya (2014).

The increase in DTPA extractable iron content of soil might be attributed to iron released during microbiological breakdown of organic matter which contributed directly in supplying available iron (Supriya, 2014). As reported by influence of organic matter on availability of iron is probably owing to its higher state of reduction developed in presence of decomposing organic matter, which subsequently reduced the $\mathrm{Fe} 3+$ to $\mathrm{Fe} 2+$ form (Jagtap et al., 2006). 


\section{Copper $\left(\mathrm{mg} \mathrm{kg}^{-1}\right)$}

Available $\mathrm{Cu}$ content (as shown in Table $1 \mathrm{~b}$ ) varied from 0.65 to $0.82 \mathrm{mg} \mathrm{kg}^{-1}, 0.69$ to 0.86 $\mathrm{mg} \mathrm{kg}$ and 0.64 to $0.83 \mathrm{mg} \mathrm{kg}^{-1}$ at transplanting, tillering stage and in postharvest soil respectively. There was an increasing trend in DTPA extractable $\mathrm{Cu}$ in soil from transplanting to tillering stage.

Table.1b Effect of vermicompost and fertilizer on $\mathrm{Cu}$ availability in soil during rice growth period

\begin{tabular}{|c|c|c|c|c|c|c|c|c|c|c|c|c|}
\hline \multicolumn{13}{|c|}{ Available Cu (mg kg $\left.{ }^{-1}\right)$} \\
\hline \multirow[t]{2}{*}{ Treatments } & \multicolumn{4}{|c|}{ Transplanting stage } & \multicolumn{4}{|c|}{ Tillering stage } & \multicolumn{4}{|c|}{ Post-harvest soil } \\
\hline & $\mathbf{F}_{\mathbf{0}}$ & $\mathbf{F}_{1}$ & $\mathbf{F}_{2}$ & Mean & $\mathbf{F}_{0}$ & $\mathbf{F}_{1}$ & $\mathbf{F}_{2}$ & Mean & $\mathbf{F}_{\mathbf{0}}$ & $\mathbf{F}_{1}$ & $\mathbf{F}_{2}$ & Mean \\
\hline $\mathbf{V}_{0}$ & 0.650 & 0.687 & 0.683 & 0.673 & 0.690 & 0.730 & 0.723 & 0.714 & 0.640 & 0.697 & 0.693 & 0.677 \\
\hline$V_{1}$ & 0.753 & 0.770 & 0.767 & 0.763 & 0.803 & 0.817 & 0.817 & 0.812 & 0.763 & 0.780 & 0.777 & 0.773 \\
\hline $\mathbf{V}_{2}$ & 0.780 & 0.803 & 0.793 & 0.792 & 0.837 & 0.853 & 0.843 & 0.844 & 0.793 & 0.813 & 0.803 & 0.803 \\
\hline $\mathbf{V}_{3}$ & 0.800 & 0.823 & 0.810 & 0.811 & 0.850 & 0.863 & 0.863 & 0.859 & 0.810 & 0.833 & 0.820 & 0.821 \\
\hline Mean & 0.746 & 0.771 & 0.763 & & 0.795 & 0.816 & 0.812 & & 0.752 & 0.781 & 0.773 & \\
\hline Sources & \multicolumn{2}{|c|}{$\operatorname{SEm}( \pm)$} & \multicolumn{2}{|c|}{$\mathrm{CD}(5 \%)$} & \multicolumn{2}{|c|}{$\operatorname{SEm}( \pm)$} & \multicolumn{2}{|c|}{$\mathrm{CD}(5 \%)$} & \multicolumn{2}{|c|}{$\operatorname{SEm}( \pm)$} & \multicolumn{2}{|c|}{$\mathrm{CD}(5 \%)$} \\
\hline Vermicompost (V) & \multicolumn{2}{|c|}{0.009} & \multicolumn{2}{|c|}{0.025} & \multicolumn{2}{|c|}{0.009} & \multicolumn{2}{|c|}{0.027} & \multicolumn{2}{|c|}{0.009} & \multicolumn{2}{|c|}{0.026} \\
\hline Fertilizer (F) & \multicolumn{2}{|c|}{0.008} & \multicolumn{2}{|c|}{ NS } & \multicolumn{2}{|c|}{0.008} & \multicolumn{2}{|c|}{ NS } & \multicolumn{2}{|c|}{0.008} & \multicolumn{2}{|c|}{0.022} \\
\hline $\mathbf{V} \times \mathbf{F}$ & \multicolumn{2}{|c|}{0.015} & \multicolumn{2}{|c|}{ NS } & \multicolumn{2}{|c|}{0.016} & \multicolumn{2}{|c|}{ NS } & \multicolumn{2}{|c|}{0.015} & \multicolumn{2}{|c|}{ NS } \\
\hline
\end{tabular}

Table.1c Effect of vermicompost and fertilizer on $\mathrm{Zn}$ availability in soil during rice growth period

\begin{tabular}{|c|c|c|c|c|c|c|c|c|c|c|c|c|}
\hline \multicolumn{13}{|c|}{ Available $\mathrm{Zn}\left(\mathrm{mg} \mathrm{kg}^{-1}\right)$} \\
\hline \multirow[t]{2}{*}{ Treatments } & \multicolumn{4}{|c|}{ Transplanting stage } & \multicolumn{4}{|c|}{ Tillering stage } & \multicolumn{4}{|c|}{ Post-harvest soil } \\
\hline & $\mathbf{F}_{\mathbf{0}}$ & $\mathbf{F}_{1}$ & $\mathbf{F}_{2}$ & Mean & $\mathbf{F}_{\mathbf{0}}$ & $\mathbf{F}_{1}$ & $\mathbf{F}_{2}$ & Mean & $\mathbf{F}_{\mathbf{0}}$ & $\mathbf{F}_{1}$ & $\mathbf{F}_{2}$ & Mean \\
\hline $\mathbf{V}_{\mathbf{0}}$ & 0.617 & 0.687 & 0.637 & 0.647 & 0.607 & 0.700 & 0.673 & 0.660 & 0.577 & 0.667 & 0.640 & 0.628 \\
\hline$V_{1}$ & 0.707 & 0.773 & 0.737 & 0.739 & 0.723 & 0.770 & 0.753 & 0.749 & 0.687 & 0.733 & 0.717 & 0.712 \\
\hline $\mathbf{V}_{2}$ & 0.770 & 0.813 & 0.777 & 0.787 & 0.783 & 0.800 & 0.793 & 0.792 & 0.743 & 0.760 & 0.753 & 0.752 \\
\hline $\mathbf{V}_{3}$ & 0.833 & 0.843 & 0.840 & 0.839 & 0.850 & 0.863 & 0.860 & 0.858 & 0.810 & 0.820 & 0.817 & 0.816 \\
\hline Mean & 0.732 & 0.779 & 0.747 & & 0.741 & 0.783 & 0.770 & & 0.704 & 0.745 & 0.732 & \\
\hline Sources & \multicolumn{2}{|c|}{$\operatorname{SEm}( \pm)$} & \multicolumn{2}{|c|}{$\mathrm{CD}(5 \%)$} & \multicolumn{2}{|c|}{$\operatorname{SEm}( \pm)$} & \multicolumn{2}{|c|}{$\mathrm{CD}(5 \%)$} & \multicolumn{2}{|c|}{$\operatorname{SEm}( \pm)$} & \multicolumn{2}{|c|}{$\mathrm{CD}(5 \%)$} \\
\hline Vermicompost (V) & \multicolumn{2}{|c|}{0.008} & \multicolumn{2}{|c|}{0.025} & \multicolumn{2}{|c|}{0.009} & \multicolumn{2}{|c|}{0.025} & \multicolumn{2}{|c|}{0.008} & \multicolumn{2}{|c|}{0.024} \\
\hline Fertilizer (F) & \multirow{2}{*}{\multicolumn{2}{|c|}{0.007}} & \multirow{2}{*}{\multicolumn{2}{|c|}{$\begin{array}{c}0.022 \\
\text { NS }\end{array}$}} & \multirow{2}{*}{\multicolumn{2}{|c|}{0.007}} & \multicolumn{2}{|c|}{0.022} & \multicolumn{2}{|c|}{0.007} & \multicolumn{2}{|c|}{0.021} \\
\hline $\mathbf{V} \times \mathbf{F}$ & & 0.015 & & & & & \multicolumn{2}{|c|}{ NS } & \multicolumn{2}{|c|}{0.014} & \multicolumn{2}{|c|}{ NS } \\
\hline
\end{tabular}

At tillering stage all the treatment combination receiving vermicompost either alone or in combination with chemical fertilizer recorded higher value of DTPA extractable $\mathrm{Cu}$ as compared to the treatment involving alone application of chemical fertilizer.
In post-harvest soil there was a gradual decrease in DTPA extractable $\mathrm{Cu}$. Irrespective of levels of chemical fertilizer treatment involving highest dose of vermicompost $\left(3.75 \mathrm{t} \quad \mathrm{ha}^{-1}\right)$ recorded significantly higher available $\mathrm{Cu}$ content ( 0.81 to $0.83 \mathrm{mg} \mathrm{kg}^{-1}$ ) which was found to be at par with the treatment receiving 
vermicompost at $2.5 \mathrm{tha}^{-1}(0.79$ to $0.81 \mathrm{mg}$ $\left.\mathrm{kg}^{-1}\right)$. Overall trend shows that DTPA extractable copper content of soil increased significantly with increasing levels of vermicompost. However, the interaction effect was found non-significant throughout the rice growth period.It might be due to addition of organic matter have increased the microbial proliferation, the microbes resulted in the release of chelating agents, which prevented micronutrients from precipitation, oxidation and leaching (Rangaraj et al., 2007). Similar findings were reported by Lakshmi (2011) and Supriya (2014).

\section{Zinc (mg kg-1)}

Available $\mathrm{Zn}$ content (as shown in Table 1c) varied from 0.62 to $0.84 \mathrm{mg} \mathrm{kg}$ at transplanting stage. There was an increasing trend in DTPA extractable $\mathrm{Zn}$ in soil from transplanting to tillering stage.

At tillering stage, there was significant improvement in zinc status of the soil among different treatments and DTPA-extractable $\mathrm{Zn}$ content varied from 0.61 to $0.86 \mathrm{mg} \mathrm{kg}^{-1}$. Irrespective of doses of fertilizer application treatment receiving higher dose of vermicompost $\quad\left(3.75 \mathrm{t} \quad \mathrm{ha}^{-1}\right)$ recorded maximum and significantly higher value ( 0.850 to $0.86 \mathrm{mg} \mathrm{kg}^{-1}$ ).

The result reveals that in post-harvest soil, there was a gradual decrease in available $\mathrm{Zn}$ content in post-harvest soil $(0.58$ to $0.82 \mathrm{mg}$ $\mathrm{kg}^{-1}$ ) which might be due to uptake of nutrients by the crop. The treatment which received higher dose of vermicompost $(3.75 \mathrm{t}$ $\mathrm{ha}^{-1}$ ) either alone or in combination with chemical fertilizer was significantly superior (0.81 to $0.82 \mathrm{mg} \mathrm{kg}^{-1}$ ).

Overall trend shows that increasing level of vermicompost resulted in significant increase in the available $\mathrm{Zn}$ during rice growth period and the interaction effect was found nonsignificant during all the observational stages.

This might be due to addition of vermicompost or organic manures resulted high rate of mineralization over the time which enhanced the $\mathrm{Zn}$ availability in soil (Supriya, 2014). The finding was in accordance with the findings of Lakshmi (2011) and Supriya (2014).

Table.1d Effect of vermicompost and fertilizer on Mn availability in soil during rice growth period

\begin{tabular}{|c|c|c|c|c|c|c|c|c|c|c|c|c|}
\hline \multicolumn{13}{|c|}{ Available $\mathrm{Mn}\left(\mathrm{mg} \mathrm{kg}^{-1}\right)$} \\
\hline \multirow[t]{2}{*}{ Treatments } & \multicolumn{4}{|c|}{ Transplanting stage } & \multicolumn{4}{|c|}{ Tillering stage } & \multicolumn{4}{|c|}{ Post-harvest soil } \\
\hline & $\mathbf{F}_{\mathbf{0}}$ & $\mathbf{F}_{1}$ & $\mathbf{F}_{2}$ & Mean & $\mathbf{F}_{\mathbf{0}}$ & $\mathbf{F}_{1}$ & $\mathbf{F}_{2}$ & Mean & $\mathbf{F}_{\mathbf{0}}$ & $\mathbf{F}_{1}$ & $\mathbf{F}_{2}$ & Mean \\
\hline $\mathbf{V}_{0}$ & 2.723 & 3.080 & 3.070 & 2.958 & 2.733 & 3.097 & 3.087 & 2.972 & 2.453 & 2.770 & 2.763 & 2.662 \\
\hline $\mathbf{V}_{1}$ & 3.343 & 3.477 & 3.420 & 3.413 & 3.360 & 3.493 & 3.440 & 3.431 & 3.010 & 3.127 & 3.080 & 3.072 \\
\hline $\mathbf{V}_{2}$ & 3.513 & 3.583 & 3.550 & 3.549 & 3.530 & 3.603 & 3.567 & 3.567 & 3.160 & 3.223 & 3.197 & 3.193 \\
\hline $\mathbf{V}_{3}$ & 3.650 & 3.687 & 3.677 & 3.671 & 3.667 & 3.703 & 3.693 & 3.688 & 3.283 & 3.317 & 3.307 & 3.302 \\
\hline Mean & 3.308 & 3.457 & 3.429 & & 3.323 & 3.474 & 3.447 & & 2.977 & 3.109 & 3.087 & \\
\hline Sources & \multicolumn{2}{|c|}{$\operatorname{SEm}( \pm)$} & \multicolumn{2}{|c|}{$\mathrm{CD}(5 \%)$} & \multicolumn{2}{|c|}{$\operatorname{SEm}( \pm)$} & \multicolumn{2}{|c|}{$\mathrm{CD}(5 \%)$} & \multicolumn{2}{|c|}{$\operatorname{SEm}( \pm)$} & \multicolumn{2}{|c|}{$\mathrm{CD}(5 \%)$} \\
\hline Vermicompost (V) & \multicolumn{2}{|c|}{0.038} & \multicolumn{2}{|c|}{0.111} & \multicolumn{2}{|c|}{0.038} & \multicolumn{2}{|c|}{0.113} & \multicolumn{2}{|c|}{0.034} & \multicolumn{2}{|c|}{0.100} \\
\hline Fertilizer (F) & \multicolumn{2}{|c|}{0.033} & \multicolumn{2}{|c|}{0.096} & \multicolumn{2}{|c|}{0.033} & \multicolumn{2}{|c|}{0.098} & \multicolumn{2}{|c|}{0.030} & \multicolumn{2}{|c|}{0.087} \\
\hline $\mathbf{V} \times \mathbf{F}$ & \multicolumn{2}{|c|}{0.066} & \multicolumn{2}{|c|}{ NS } & \multicolumn{2}{|c|}{0.066} & \multicolumn{2}{|c|}{ NS } & \multicolumn{2}{|c|}{0.059} & \multicolumn{2}{|c|}{ NS } \\
\hline
\end{tabular}




\section{Manganese ( $\mathrm{mg} \mathrm{kg}^{-1}$ )}

Available Mn content (as shown in Table 1d) varied from 2.72 to $3.69 \mathrm{mg} \mathrm{kg}^{-1}, 2.74$ to 3.70 $\mathrm{mg} \mathrm{kg}-1$ and at transplanting, tillering stage soil respectively. An increasing trend was observed in available $\mathrm{Mn}$ in soil from transplanting to tillering stage.

At tillering stage all the treatment combination receiving vermicompost either alone or in combination with chemical fertilizer recorded significantly higher value of DTPA extractable $\mathrm{Mn}$ as compared to the treatment involving alone application of chemical fertilizer.

In post-harvest soil, there was decline in DTPA extractable $\mathrm{Mn}$ for all the treatment combinations as compared to tillering stage and it ranged from 2.45 to $3.32 \mathrm{mg} \mathrm{kg}^{-1}$. It might be due to uptake of nutrients by the crop.

Irrespective of chemical fertilizer application treatment involving highest dose of vermicompost $\quad\left(3.75 \mathrm{t} \quad \mathrm{ha}^{-1}\right)$ recorded significantly higher available $\mathrm{Mn}$ content ( 3.28 to $3.32 \mathrm{mg} \mathrm{kg}^{-1}$ ) which was found to be at par with the treatment receiving vermicompost at $2.5 \mathrm{t} \mathrm{ha}^{-1}$ (3.16 to $3.22 \mathrm{mg}$ $\left.\mathrm{kg}^{-1}\right)$.

It can be seen from above data that significant build-up of micronutrients ( $\mathrm{Fe}, \mathrm{Cu}, \mathrm{Zn}$ and $\mathrm{Mn}$ ) was recorded in post-harvest soil of rice crop with application of increasing dose of vermicompost and chemical fertilizer separately and in combination.

The increase in micronutrients might be due to the fact that micronutrient cations form complex with organic matter and also get incorporated in its structural component. Some micro-organisms also assimilate these cations for metabolic transformations and thus temporarily immobilize in their body which is slowly released after death of microbes through mineralization.

Thus, during decomposition of organic matter these nutrient cations get slowly released into soil solution. The cationic micronutrients also form organo-metallic complexes i.e. chelates with organic molecules and thus, prevented from precipitation and unavailability in soil.

\section{References}

Arancon, N.Q., Edwards C.A., Bierman, P., Metzger, J.D. and Lucht, C. 2005. Effects of vermicompost produced from cattle manure, food waste and paper waste on the growth and yield of peppers in the field. Pedobiologia.49, 297-306.

FAO (2017). FAO Statistical data, http:stat.www.faostat.org.in

Jagtap, P.B., Patil, T.D., Nimbolkar, C.A. and Kadlag. A.D. 2006. Influence of integrated nutrient management on soil properties and release of nutrients in saline sodic soil. Journal of Indian Society of Soil Science. 55, 147-156.

Kale, R.D., Mallesh, B.C., Kubra, B. and Bagyaraj, D.J. 1992. Influence of vermicompost application on the available macronutrients and selected microbial populations in a paddy field. Soil Biology and Biochemistry.24(12): 1317-1320.

Lindsay, W.L. and Norvell, W.A. 1978. Development of DTPA soil test for zinc, iron, manganese and copper. Soil Science Society of American Journal. 42, 421-428.

Lakshmi, S.R. 2011. Vermicomposting for effective waste management and its evaluation under INM in rice-pulse cropping system. Ph.D. Thesis, Acharya N.G. Ranga Agricultural University, Hyderabad. 
Padmavathiamma, P.K., Lib, L.Y., and Kumari, U.R. 2008. An experimental study of vermi-biowaste composting for agricultural soil improvement. Bioresource Technology. 99, 1672 1681.

Rashid A. 2005. Establishment and management of micronutrient deficiencies in soils of Pakistan: A review. Soil Environment. 24: 1-22.

Rangaraj, T., Somasundaram, E., Mohamed Amanullah, M., Thirumurugan, V., Ramesh, S. and Ravi, S. 2007. Effect of agroindustrial wastes on soil properties and yield of irrigated finger millet (EleusinecoracanaL.Gaertn) in coastal soil. Research journal of agriculture and biological sciences3(3): 153-156.
Singh, A.K., Khan, S.K. and Nongynrih,P. 1999. Transformation of zinc in wetland rice soils in relation to nutrition of rice crop.Journal of Indian Society of Soil Science. 47, 248-253.

Supriya, N.O. 2014. Effect of enriched urban solid waste compost on soil properties, yield and uptake of nutrients by rice in submerged soil. M.Sc. (Agri.) Thesis,University of Agricultural Sciences, Bangalore.

Tharmaraj, K., Ganesh P., Kolanjinathan, K., Suresh Kumar, R and Anandan, A. 2011. Influence of vermicompost and vermiwash on physico chemical properties of rice cultivated soil. Current Botany. 2(3):18-21.

\section{How to cite this article:}

Alpana Kusum, Shankar Jha, S. S. Prasad and S. P. Singh. 2020. Micronutrient Availability as Influenced by Household Waste based Vermicompost Application in Calcareous Soil of Bihar during Rice Growth Period. Int.J.Curr.Microbiol.App.Sci. 9(02): 960-966.

doi: https://doi.org/10.20546/ijcmas.2020.902.112 